\title{
Illusions of the Reality, the Dangers of Cultism
}

\author{
Uche Nnyagu PhD* \\ Nnamdi Azikiwe University, Awka \\ *Corresponding Author \\ Uche Nnyagu PhD
}

\section{Article History}

Received: 09.06.2020

Accepted: 16.06 .2020

Published: 25.06.2020

\begin{abstract}
Fiction, though a work of imagination, aptly represents life. This is why Laurence Perrince says that fiction must in addition to the entertainment it offers, educate. By education, he means that fiction helps human beings to live. A writer has the onus to represent the society the way he perceives it, subtly condemns societal ills so that the reader reads and sees the consequences of the ills on the perpetrators and then, avoid such ill acts in order not to be visited by the fate of the characters in the fictional work. This is why it is said that fiction is a mirror of the author's society. What happens around the author inspires him. The inspiration that led to the conception of this story is the fact that youths of the contemporary society are lured into cultism. Many tantalising promises are made to them but sooner after they had joined, they discover that they have made the deadliest mistake of their life but they find it difficult to come out because of the covenant they had entered into. I decided to write this short story to x-ray to the unwary the dangers of cultism and the reason why they must shun it.
\end{abstract}

Keywords: Fiction, education, cultism.

\section{INTRODUCTION}

This short story is my own contribution to the society. According to Wilbur, L.P, a novelist has a duty to use his imaginative work to reform the society. He recommends that the author meticulously selects his fictional dream and manages it well in his fiction in such a way that the work in a way or the other, must aggect the lives of the readers. This is why Uche Nnyagu in his Literature and the Literate maintains that authors are gadflies who use their work to condemn the aberrations in the society. The way he puts it, "Writers are gadflies; the onus is on then to fight against ills in his society. However, a writer has no gun or knife to fight the evil doers but he has pen which is believed to be mightier than sword" (138). Writers, use fictional characters to represent real persons they want to attack. No writer thereforewrites in a vacuum; what he experienced inspires him. What inspired the writing of this short story was the perilous acts of the cultists in the society. Unwary youths are lured into the cultism with a lot of lofty promises. Once they get in, they discover that they have been deceived. However, to come out becomes difficult. Since literature, according to Thrall, William Flint \& Addison Hibbard, is a means of reforming the society, I decided to vividly X-Ray the ills and dangers of cultism with the aim of getting the intended members wary of their intention as to discourage them from becoming members of any cult.

\section{ILLUSIONS OF REALITY}

When I pinched myself and felt the pains, it dawned on me that I was actually not dreaming. "What is this I have done to myself?" I said in a soliloquy. Dejectedly, I lowered my face and began to gape vacantly at a direction. I wished it was happening in a dream. I wished too that I could turn back the hands of the clock. Although I have heard people say that men don't cry, that Wednesday, I cried and wailed like a woman.

I had a reminiscence of how it happened and I cursed the day I was born. I am the first child in my family and so, I had been the hope of the family as my father would always remind me to live positively so that my younger siblings would follow my pathways. I have six siblings. Ifeanyi and I are the only males. Ifeanyi is the youngest. Others are females.

Copyright @ 2020: This is an open-access article distributed under the terms of the Creative Commons Attribution license which permits unrestricted use, distribution, and reproduction in any medium for non commercial use (NonCommercial, or CC-BY-NC) provided the original author and source are credited. 
About seven years ago, I gained admission to study electrical engineering in one of the famous federal universities in the eastern part of Nigeria. Although it was a long time ago, I have not forgotten how my father shedded tears when I showed him my admission letter. I knew it was not tears of joy so I stood beside him gaping at him. As I watched him, I wondered why he should weep instead of being happy for my success. I had expected that he would draw me passionately close to himself as he had always done whenever anyone of us did him proud, and say, "my child, I am proud of you."

As if he knew what was going on in my mind, he cleared his throat, raised his face and when our eyes met, he smiled at me. I was not moved by his smiles because I knew they were not really inspired. "My son," he managed to call, his voice was shaky. "Sit down," he said pointing at an outdated sofa in our godforsaken living room as if I didn't see any place to sit.

I sat down and looked round the place. For what seemed like ages, there was silence as the both of us sat looking at each other. At a time, my father cleared his throat and called, "Emenike."

"Sir," I responded without looking in his direction.

"My son, I am happy that you are successful in the entrance exam. I knew you would make it because you were never a dunce." He paused to clear his throat again. "My son, why it seemed as though I was unhappy about your achievement was because as our people say, one does not go to see a newly born child empty-handed," he said as I gaped at him.

I understood what he meant. He was only a poor teacher in one private primary school in my community. I wanted to suggest to him again that I should go and learn a trade since there was no money to send me to the university. I had made the suggestion many times in the past but he had always insisted that I must go to the university. "My son," he suddenly called.

"Sir."

"I was the one who insisted that you would go to school. Yes I did. It is true that I do not have the wherewithal to send you to the university but I am optimistic that God will not close his ears to my pleas. He created coconut and provided water for it to drink. I know he will not forsake me. My son, you must go to school. Education is the only worthwhile empowerment any positive thinking parent can give to his or her child. I am ready to sell my last portion of land to give you education. Our people say that one needs to dance the dance that is prevailing in one's own time: that dance is education. We are living in a dynamic world my son. In our society today, one is blind if one does not have western education. We are living in a dynamic world; in the past, a man would support his first son to go and learn trade or craft so that he would help him to train the younger ones. Today, education trends and our people have understood that anybody who fails to train his children especially the first son in the university will soon regret it. That is why every parent does everything possible to send his or her children to university. Our people have understood the importance of education and that is why everybody; the literates and the illiterates insist that their children would go to university. I blame our government that has taken the cost of the western education to the iroko tree." He took a deep breath, shook his head and continued, "My son, you will go to university. If there is life, by the time you graduate and begin to work, you will help to train your younger ones."

I spontaneously knelt down and thanked him. To be a graduate of engineering has always been my wish. My father held my hand and drew me up. "My son, sit down," he said. His voice was shaky and I looked him in the face to see if he was crying but he smiled. I knew that the smile was not inspired. He used his lapa to dab his eyes so that I would not notice if he was shedding tears or not. He looked me straight in the face. "It is my responsibility to give you and your siblings good education. I will do my best even if it entails that I will go naked and without food. I have always believed that tomorrow will be better."

I nodded my head, a way of acknowledging his love and sacrifice.

"My son," he called and I raised my face and looked straight in his face. "Please, my knees are on the ground though a man should not kneel down for his child. I will do anything possible to send you to the university but please, when you get to the university, behave yourself. Remember where you come from. Our people say that a poor person always behaves like an indisposed person. Do not look at the aristocratic ones; those who born with golden spoons in their mouths. Remember the family you come from and please my son, do not join any secret society. Be a good ambassador of our family. I know God will make a way where there is no way: he does not allow one to have a burden one cannot handle." 
I looked him in the face and promised him that I would not disappoint him. I determined not to disappoint my family. I prayed that God would bless my father and help me to graduate with good point so that a good firm would employ me. I began to fantasize about my work after graduation and how I would be helping my parents and siblings from my tantalizing salary. It was however, in my second semester of my second year in the university that the devil eventually won my heart like he did Dr Faustus'. I curse the day with my wounded heart. I had detested anything cultism but Nduka my so-called best friend lured me into it. God will never forgive him.

To cut the long story short, the cult that I joined promised to protect her members from any form of plight. Nduka had given me the illusion that the cult would endear me to greater potentials. He tactically made me to believe that no graduate in Nigeria would make it in life if he or she does not join any cult. I will not tell lies, I was always protected most of the times as promised. Even when I never sat for any exams, I never had carry over. The fraternity would always use mysterious manipulations to make sure that her members never had failure in any of the exams. As I was made to understand, the Fraternity Lord is the head of the cult. He would use mysterious means to coerce lecturers to award high marks to members of his cult. I later understood that most lecturers from my university and other universities around belong to the cult too. The members of the fraternity had no problems getting any beautiful girl they needed. Many young men joined the cult just to be able to have any class of girls they wanted at any time. I presume that girls love cultists. Many girls I knew preferred to have prominent cultists as their boyfriends so it was always so easy for cultists to get their choice of girls. The cult that I joined was among the most formidable: other cultists feared us. However, each time I remembered my father's advice, I would long to denounce but Nduka would always quickly remind me of the consequences of evicting and I would never think of absconding. I enjoyed my stay in the university and my membership in the fraternity was never a secret. As I said, we were formidable and even veteran Nigerian politicians loved to associate with us. During elections, they would ask for our services. We hardly had time for our studies and we were never punctual to lectures. Most undergraduates thought we would not graduate but we made it.

It appalled many people who knew I was a cultist and who thought that I would not graduate when I eventually graduated. It was somebody who saw my name in the NYSC list that called me on the phone to tell me. I didn't waste time to go for my certificate and after my NYSC, I didn't waste time to send my CV to many reputable companies in Nigeria. From my savings from what we were paid by the politicians we rendered our services to, I bribed one of the high officials of the company that I had applied and he promised he would help me get the job. I knew he would do it because as he said, the amount I offered him was higher than what others had offered him as bribes. A few weeks after, I got a call from a friend who said to me, "Emenike, congratulations, your name is among the successful names shortlisted for immediate employment by Shell BP."'With profound euphoria, the phone fell off my hand as I jumped up and began to dance to an unrehearsed tune. I was still dancing in the room when my dad pushed the door open without knocking. "Emenike," he called.

“Sir," I answered. I was about telling him about the news when he handed a copy of Vanguard Newspaper to me.

"My son, at last you made it. I thank God that the enemy would not laugh at me. They said that I was stupid for selling portions of the land to send you to the university. My son, I am happy that you have made me a hero. At least, those who said I was stupid will now realize that what I did was the wisest thing anyone can do. They said it was an unwise decision to sell my land to send you to the university and I told them that a mad man in the street is going about with his senses. I knew you would make me proud and I didn't listen to them.”

Before $1 \mathrm{pm}$ the following day, it was Wednesday, I was already at the office in Port Harcourt for my employment. I had left my hometown Uguta very early in the morning as not to be late. There were many of us who had come to collect their appointment letters too. Soon, it was my turn to go in and collect mine. I stood up from my seat and gallantly walked into the Manager's office. "Good evening Sir," I greeted the man issuing the letters as I stepped in.

“Good evening, dear. Your name, please?"

"Nwokeocha, Emenike, Sir," I said as I fixed a gape at him expecting him to shake my hand and say 'congratulations' to me.

"Nwokeocha?" the man rather said looking at me in an astonished way as if he saw a ghost. He removed his eyeglasses and dropped them on the table and looked into my face. I wondered what the man was up to. I didn't know why the Management of the firm should have such a mean person as one of the persons to attend to us. He seemed not to be happy that the firm was recruiting, otherwise, he would have been cheerful and warmly received us. I wanted to remind him why I had come when he cleared his throat and said to me. "Young man, I am sorry." 
“Sorry for what?" I asked oblivious of when I did.

"Based on the record from the university you graduated from about your involvement in cultism, the management of the company has decided to drop you."

I was not sure I heard him well. He shook his head and took a deep breath. "It is a pity that a handsome young man like you decided to ruin your life."

I fell on the ground and pleaded for leniency. "What shall I tell my people? Sir, please, I am no longer a cultist. I ... I ..." I was choked.

\section{THE DANGER OF CULTISM}

"Young man, please stand up and leave so that I can see other people. I am sorry, there is nothing we can do to help you. Maybe you are not aware that your university has revoked your certificate. Good day," he said and dejectedly, I walked out of the office determined to take away my life.

\section{REFERENCES}

1. Perine, Laurence (1978). Literature: Structure, Sound and Sense. New York: Harcourt Brace.

2. Wilbur, L.P. (2001). The Seven Key Elements of Fiction. London: Robert Hale.

3. Nnyagu, Uche. (2018). Literature and the Literate. Germany: Scholar.

4. Thrall, William Flint and Addison Hibbard (1936). A Handbook to Literature. New York: The Odyssey Press 